\title{
Role of phosphoglucomutase in regulating trehalose metabolism in Nilaparvata lugens
}

\author{
Bi-Ying Pan ${ }^{1} \cdot$ Yong-Kang $\mathrm{Liu}^{1} \cdot$ Hong-Kai Wu ${ }^{1} \cdot$ Xiao-Qing Pang ${ }^{1} \cdot$ Shi-Gui Wang ${ }^{1} \cdot$ Bin Tang $^{1} \cdot$ Cai-Di Xu ${ }^{2}$ (I)
}

Received: 10 October 2019 / Accepted: 3 January 2020 / Published online: 23 January 2020

(C) The Author(s) 2020

\begin{abstract}
Phosphoglucomutase (PGM) is a key enzyme in glycolysis and gluconeogenesis, regulating both glycogen and trehalose metabolism in insects. In this study, we explored the potential function of phosphoglucomutase (PGM) using RNA interference technology in Nilaparvata lugens, the brown planthopper. $P G M 1$ and $P G M 2$ were found highly expressed in the midgut of brown planthoppers, with different expression levels in different instar nymphs. The glycogen, glucose, and trehalose levels were also significantly increased after brown planthoppers were injected with dsRNA targeting PGM1 (dsPGM1) or PGM2 (dsPGM2). In addition, injection of dsPGM1 or dsPGM2 resulted in increased membrane-bound trehalase activity but not soluble trehalase activity. Furthermore, the expression of genes related to trehalose and glycogen metabolism decreased significantly after injection with dsPGM1 and dsPGM2. The expression levels of genes involved in chitin metabolism in the brown planthopper were also significantly decreased and the insects showed wing deformities and difficulty molting following RNAi. We suggest that silencing of PGM1 and PGM2 expression directly inhibits trehalose metabolism, leading to impaired chitin synthesis.
\end{abstract}

Keywords Nilaparvata lugens $\cdot$ Phosphoglucomutase $\cdot$ Trehalose and glycogen metabolism $\cdot$ Chitin metabolism $\cdot$ RNAi

Electronic supplementary material The online version of this article (https://doi.org/10.1007/s13205-020-2053-5) contains supplementary material, which is available to authorized users.

\section{Cai-Di Xu}

xucaidi001@163.com

Bi-Ying Pan

15715784740@163.com

Yong-Kang Liu

hznu_yongkang@163.com

Hong-Kai Wu

18888929312@139.com

Xiao-Qing Pang

pxq17816111830@163.com

Shi-Gui Wang

sgwang@hznu.edu.cn

Bin Tang

tbzm611@yahoo.com

1 College of Life and Environmental Sciences, Hangzhou Normal University, Hangzhou 310036, Zhejiang, People's Republic of China

2 College of Education, HangzhouNormal University, Hangzhou 310036, Zhejiang, People's Republic of China

\section{Introduction}

Rice (Oryza sativa L.) is the most important cereal crop in China. However, rice is threatened by various pests during production and storage, among which Nilaparvata lugens Stål (brown planthopper) is one of the most harmful (Zhang et al. 2017b; Boddupally et al. 2018). N. lugens can directly damage rice and spread various rice viral diseases, such as rice grass and rice ragged stunts (Cheng et al. 2013). Most rice production relies on the use of chemical insecticides to control brown planthoppers which inevitably causes environmental pollution. In addition, the use of pesticides also kills the natural predators of brown planthopper and can induce resistance, eventually leading to their resurgence of crop disease (Becker et al. 1996; Tanaka et al. 2000; Nauen and Denholm 2005; Bottrell and Schoenly 2012).

Carbohydrate metabolism is important central because it is a bridge to biosynthetic pathways for proteins, lipids, nucleic acids, and secondary metabolites. Trehalose plays a very important role in the development and physiological activities of insects as an important sugar in haemolymphs (Zhang et al. 2017b; Becker et al. 1996; Elbein et al. 2003; Tang et al. 2010). Glycogen is also another important

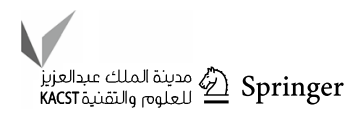


metabolite (Tolmasky et al. 2001; Liu et al. 2009), which is mainly synthesised and stored in fat bodies. Glycogen can be rapidly converted into trehalose and glucose in other tissues when insects need a supply of energy (Tang et al. 2012). The enzyme phosphoglucomutase (PGM) plays a key role in the interconversion of trehalose and glycogen in insects.

PGM is a conserved enzyme, ubiquitous in animals, plants, and microorganisms catalysing the interconversion of glucose-6-phosphate (G-6-P) and glucose-1-phosphate (G-1-P) (Jin et al. 2018; Egli et al. 2010; Stray-Pedersen et al. 2014; Weyler and Heinzle 2015; Liu 2013). Because glucose-6-phosphate is an important central metabolite, PGM plays an important role in the metabolism of proteins, lipids, and nucleic acids and is key for the development of plants (Egli et al. 2010; Paparelli et al. 2013; Malinova et al. 2014) and some microorganisms (Liu 2013). In humans, there are four PGM isoenzymes namely PGM1, PGM2, PGM3, and PGM5, which are encoded by different genes (Jin et al. 2018).

At present, there are few studies investigating PGMs in insects or invertebrates. Because PGM controls the interconversion between G-6-P and G-1-P, which is the only way to convert trehalose into glycogen, PGM has an important role in trehalose and glycogen metabolism in the brown planthopper. In this study, we further explore the role of PGM in trehalose and glycogen metabolism. A greater understanding of the role of PGM will enable its potential use as a new target for green insecticides.

\section{Materials and methods}

\section{Experimental materials}

Nilaparvata lugens was obtained from the Hangzhou population of the China Rice Research Institute. The rice used for feeding $(O$. sativa) was the susceptible Taichung Native 1 (TN1) strain. Brown planthoppers were maintained at a temperature of $25 \pm 1^{\circ} \mathrm{C}$, a light dark cycle of $16 \mathrm{~h}$ light and $8 \mathrm{~h}$ dark, and a relative humidity of $70 \pm 5 \%$. The insects used for RNA interference (RNAi) microinjection experiments were nymphs grown to the fifth instar.

\section{RNA extraction and CDNA preparation}

Total RNA was obtained from the brown planthopper by extraction using the TRIzol reagent and the RNA integrity was determined by electrophoresis on $1 \%$ agarose gels. The concentration and purity of total RNA was determined using a Nanodrop 2000 spectrophotometer (Thermo Fisher Scientific, Waltham, MA, USA). cDNA was synthesised using the PrimeScript RT reagent Kit with gDNA Eraser
(TaKaRa, Nojihigashi, Japan) according to the manufacturer's instructions.

\section{Synthesis of dsRNA}

The dsRNA primers used for the synthesis of dsPGM1, dsPGM2, and dsGFP were designed using Primer 5 software and are listed in Table 1. cDNA was amplified with the primers of interest as follows: 40 cycles of $95{ }^{\circ} \mathrm{C}$ for $30 \mathrm{~s}, 58^{\circ} \mathrm{C}$ for $30 \mathrm{~s}$, and $72{ }^{\circ} \mathrm{C}$ for $45 \mathrm{~s}$, followed by a final extension at $72{ }^{\circ} \mathrm{C}$ for $10 \mathrm{~min}$. The PCR products were subjected to $\mathrm{T}$ cloning and subsequently amplified with primers containing the $\mathrm{T} 7$ promoter sequence. To synthesise dsRNA, crossPCR reactions were performed using the T7 RiboMAX ${ }^{\mathrm{TM}}$ Express RNAi System kit (Promega, Madison, WI, USA). The integrity of the dsRNA was determined by gel electrophoresis, and the concentration and purity were measured using NanoDrop 2000.

\section{Microinjection of the brown planthopper}

The brown planthoppers were anesthetised with $\mathrm{CO}_{2}$ and then placed in the groove of a pre-prepared agarose gel. Using a standard capillary under a microscope, dsGFP, dsPGM1, and dsPGM2 (50 ng) were injected into the lateral epidermis of the two pairs of hind paws in the brown planthopper chest. The injected brown planthoppers were transferred to a glass tube containing fresh rice, and the surviving brown planthoppers were used for subsequent experiments within $48 \mathrm{~h}$ after injection. One hundred brown planthoppers were employed in each treatment and 10 were used in RNA isolation for quantitative real-time PCR (qRT-PCR).

\section{Experimental materials' collection}

Experimental materials to examine developmental expression patterns in the brown planthopper were collected in triplicate every $24 \mathrm{~h}$, over a period extending from the first day of the fourth instar nymph to the third day of adulthood. In addition, the tissue materials from the head, foot, wing, epidermis, ovary, fat body, and midgut were obtained through anatomical dissection using Leica EZ4 (Leica, Wetzlar, Germany). Different tissue materials were taken from more than 200 adults, and materials for each developmental stage were collected from 10 individuals. All experimental materials were stored at $-80{ }^{\circ} \mathrm{C}$.

\section{Gene expression by qRT-PCR}

Total RNA was extracted from the experimental materials to examine developmental and tissue expression patterns, and cDNA was synthesised as previously described. The relative expression levels of the $P G M 1$ and $P G M 2$ genes at the 
Table 1 Primers used for qRT-PCR and for construction of dsPGM1, dsPGM2, and dsGFP

\begin{tabular}{|c|c|c|c|c|c|}
\hline Primer name & Gene name & $\begin{array}{l}\text { Genebank accession } \\
\text { number }\end{array}$ & Forward primer $\left(5^{\prime}-3^{\prime}\right)$ & Reverse primer $\left(5^{\prime}-3^{\prime}\right)$ & Length (bp) \\
\hline QN118S & & & $\begin{array}{l}\text { CGCTACTACCGA } \\
\text { TTGAA }\end{array}$ & $\begin{array}{l}\text { GGAAACCTTGTTACG } \\
\text { ACTT }\end{array}$ & 165 \\
\hline QNIPGM1 & Phosphoglucomutase 1 & KU556839.1 & $\begin{array}{l}\text { AACGAGACGGTGGGA } \\
\text { GAC }\end{array}$ & $\begin{array}{l}\text { TCCTGGTAAGTGTTG } \\
\text { AGCC }\end{array}$ & 127 \\
\hline QN1PGM2 & Phosphoglucomutase 2 & KU556840.1 & $\begin{array}{l}\text { AGAGGAAGGTTGGGA } \\
\text { GTG }\end{array}$ & $\begin{array}{l}\text { CATAATTCGCGGAGA } \\
\text { TAAG }\end{array}$ & 141 \\
\hline QNIGP & Glycogen Phosphorylase & KU556838.1 & $\begin{array}{l}\text { GCTGCCTATGGCTAT } \\
\text { GGTATTC }\end{array}$ & $\begin{array}{l}\text { TCTGAGTGTTGACCC } \\
\text { ACTTCTTG }\end{array}$ & 202 \\
\hline QN1GS & Glycogen synthase & KU556837.1 & $\begin{array}{l}\text { GCTCCAAAGCCTATG } \\
\text { TTTCTACTG }\end{array}$ & $\begin{array}{l}\text { TGGTAACCCCTGTCC } \\
\text { CTCA }\end{array}$ & 160 \\
\hline QNLUGPase & $\begin{array}{l}\text { UDP-Glucose pyrophos- } \\
\text { phorylase }\end{array}$ & KU556842.1 & $\begin{array}{l}\text { ATACAAGATGGCGGC } \\
\text { TAA }\end{array}$ & $\begin{array}{l}\text { TTGTGGCAGTTGATA } \\
\text { GAGC }\end{array}$ & 136 \\
\hline QNITPS1 & $\begin{array}{l}\text { Trehalose-6-phosphate } \\
\text { synthase } 1\end{array}$ & GQ397450 & $\begin{array}{l}\text { AAGACTGAGGCGAAT } \\
\text { GGT }\end{array}$ & $\begin{array}{l}\text { AAGGTGGAAATGGAA } \\
\text { TGTG }\end{array}$ & 154 \\
\hline QN1TPS2 & $\begin{array}{l}\text { Trehalose-6-phosphate } \\
\text { synthase } 2\end{array}$ & KU556826 & $\begin{array}{l}\text { AGAGTGGACCGCAAC } \\
\text { AACA }\end{array}$ & $\begin{array}{l}\text { TCAACGCCGAGAATG } \\
\text { ACTT }\end{array}$ & 161 \\
\hline $\begin{array}{l}\text { QNITPS3 } \\
\text { (Tang et al. } \\
\text { 2019) }\end{array}$ & $\begin{array}{l}\text { Trehalose-6-phosphate } \\
\text { synthase } 3\end{array}$ & KU556827 & $\begin{array}{l}\text { GTGATGCGTCGGTGG } \\
\text { CTAT }\end{array}$ & $\begin{array}{l}\text { CCGTTCATCATTGGG } \\
\text { CATAGT }\end{array}$ & 224 \\
\hline QNITRE1-1 & Trehalase 1-1 & FJ790319 & $\begin{array}{l}\text { GCCATTGTGGACAGG } \\
\text { GTG }\end{array}$ & $\begin{array}{l}\text { CGGTATGAACGAATA } \\
\text { GAGCC }\end{array}$ & 132 \\
\hline QNITRE1-2 & Trehalase 1-2 & KU556829 & $\begin{array}{l}\text { GATCGCACGGAT } \\
\text { GTTTA }\end{array}$ & $\begin{array}{l}\text { AATGGCGTTCAA } \\
\text { GTCAA }\end{array}$ & 178 \\
\hline QNITRE2 & Trehalase 2 & GQ397451 & $\begin{array}{l}\text { TCACGGTTGTCCAAG } \\
\text { TCT }\end{array}$ & $\begin{array}{l}\text { TGTTTCGTTTCG } \\
\text { GCTGT }\end{array}$ & 197 \\
\hline QNIHK & Hexokinase & KU556830 & $\begin{array}{l}\text { GGTGCGAGAAGAAGT } \\
\text { GAAG }\end{array}$ & $\begin{array}{l}\text { GTGAAACCCATTGGT } \\
\text { AGAGT }\end{array}$ & 147 \\
\hline QNIGFAT & $\begin{array}{l}\text { Glutamine: fructose- } \\
\text { 6-phosphate aminotrans- } \\
\text { ferase }\end{array}$ & KU556833 & $\begin{array}{l}\text { CCTCCCAGTTCATCT } \\
\text { CGC }\end{array}$ & $\begin{array}{l}\text { CCAAGTTCTTCAAAC } \\
\text { CCTTTAT }\end{array}$ & 105 \\
\hline N1G6Pase & Glucose-6-phosphatase & KU556841.1 & $\begin{array}{l}\text { AGACCCTGGCAGTAG } \\
\text { AATAG }\end{array}$ & $\begin{array}{l}\text { GGGAAGTGAGCC } \\
\text { GAAAT }\end{array}$ & 132 \\
\hline N1G6PI1 & $\begin{array}{l}\text { Glucose-6-phosphate } \\
\text { isomerase } 1\end{array}$ & KU556832.1 & $\begin{array}{l}\text { GTTCACGGTCGTCTG } \\
\text { GAAAG }\end{array}$ & $\begin{array}{l}\text { TGACTGCTCCGTTTC } \\
\text { ACTCT }\end{array}$ & 82 \\
\hline QN1G6PI2 & $\begin{array}{l}\text { Glucose-6-phosphate } \\
\text { isomerase } 2\end{array}$ & KU556831.1 & $\begin{array}{l}\text { AACAAGGCGACATGG } \\
\text { AATCG }\end{array}$ & $\begin{array}{l}\text { ACCATTTGTTCCTGG } \\
\text { TTCGC }\end{array}$ & 85 \\
\hline QN1G6PI3 & $\begin{array}{l}\text { Glucose-6-phosphate } \\
\text { isomerase } 3\end{array}$ & XM_022345379.1 & $\begin{array}{l}\text { ATGTCACAGTGCATG } \\
\text { TCGTG }\end{array}$ & $\begin{array}{l}\text { ACCTGCTCTCATTGA } \\
\text { TGCCA }\end{array}$ & 120 \\
\hline QNIGNPNA & $\begin{array}{l}\text { Glucosamine-6-phosphate } \\
N \text {-acetyltransferase }\end{array}$ & KU556834 & $\begin{array}{l}\text { TGAGCTGCTGAAGAC } \\
\text { ACT }\end{array}$ & $\begin{array}{l}\text { CCTGAATAACGGTGA } \\
\text { TGTA }\end{array}$ & 179 \\
\hline QNIUAP & $\begin{array}{l}\text { UDP- } N \text {-acetylglucosamine } \\
\text { pyrophosphorylase }\end{array}$ & JF330415 & $\begin{array}{l}\text { ACGACAGATTAAAGC } \\
\text { CGATAC }\end{array}$ & $\begin{array}{l}\text { TACCTTGTCCACCAG } \\
\text { CCA }\end{array}$ & 147 \\
\hline QN1CHS1 & Chitin synthase 1 & AEL88648 & $\begin{array}{l}\text { CCGCAAACGATTCCT } \\
\text { ACAGA }\end{array}$ & $\begin{array}{l}\text { AGGTCCTTGACGCTC } \\
\text { ATTCC }\end{array}$ & 222 \\
\hline QNlCHS1a & Chitin synthase $1 \mathrm{a}$ & JQ040014 & $\begin{array}{l}\text { TGTTCTTGCTACAAC } \\
\text { TCAATAAA }\end{array}$ & $\begin{array}{l}\text { ACACCAATCCGATAG } \\
\text { GCTC }\end{array}$ & 141 \\
\hline QNlCHS1b & Chitin synthase $1 b$ & JQ040013 & $\begin{array}{l}\text { GCTGTCTTTGCTTTC } \\
\text { TTCAT }\end{array}$ & $\begin{array}{l}\text { ACACCAATCCGATAG } \\
\text { GCTC }\end{array}$ & 187 \\
\hline dsNlPGM1 & Phosphoglucomutase 1 & & $\begin{array}{l}\text { GGCAAGCGTTCCTTA } \\
\text { GAG }\end{array}$ & $\begin{array}{l}\text { CAGCCACATCCTTTT } \\
\text { CATC }\end{array}$ & 553 \\
\hline dsNlPGM1-T7 & Phosphoglucomutase 1 & & $\begin{array}{l}\text { GGCAAGCGTTCCTTA } \\
\text { GAG }\end{array}$ & $\begin{array}{l}\text { CAGCCACATCCTTTT } \\
\text { CATC }\end{array}$ & 603 \\
\hline dsNlPGM2 & Phosphoglucomutase 2 & & $\begin{array}{l}\text { CAACACTTCAAACGG } \\
\text { AGGA }\end{array}$ & $\begin{array}{l}\text { CCGCATAGGGACCAG } \\
\text { TAA }\end{array}$ & 311 \\
\hline
\end{tabular}


Table 1 (continued)

\begin{tabular}{llccc}
\hline Primer name & Gene name & $\begin{array}{l}\text { Genebank accession } \\
\text { number }\end{array}$ & Forward primer (5'-3') & Reverse primer (5'-3') \\
\hline dsNlPGM2-T7 & Phosphoglucomutase 2 & CAACACTTCAAACGG & CCGCATAGGGACCAG & 361 \\
& & AGGA & TAA \\
dsGFP & Green fluorescent protein & AAGGGCGAGGAGCTG & CAGCAGGACCATGTG \\
& & TTCACCG & ATCGCGC \\
dsGFP-T7 & Green fluorescent protein & AAGGGCGAGGAGCTG & CAGCAGGACCATGTG \\
& & TTCACCG & ATCGCGC \\
\hline
\end{tabular}

T7: GGATCCTAATACGACTCACTATAGG

different developmental stages and tissues were analysed by qRT-PCR using the $18 S$ gene as an internal reference (Zhao et al. 2016). The reaction contained $10 \mu \mathrm{L}$ of SYBR Premix Ex Taq (TaKaRa, Nojihigashi, Japan), $1 \mu \mathrm{L}$ of template cDNA, $1 \mu \mathrm{L}$ of forward primer, $1 \mu \mathrm{L}$ of reverse primer, in a $20 \mu \mathrm{L}$ final reaction volume. The sequences of the qRT-PCR primers are shown in Table 1 . The PCR amplification procedure included, pre-denaturation at $95^{\circ} \mathrm{C}$ for $2 \mathrm{~min}, 39$ cycles of denaturation at $95^{\circ} \mathrm{C}$ for $30 \mathrm{~s}$, annealing at $55-60{ }^{\circ} \mathrm{C}$ for $30 \mathrm{~s}$, and dissociation curve at $65-95{ }^{\circ} \mathrm{C}$ for $5 \mathrm{~s}$.

The relative expression levels of the target genes involved in trehalose and chitin metabolism in the brown planthopper $48 \mathrm{~h}$ after RNAi treatment were examined in triplicate using the SYBR Premix Ex Taq kit. The quantitative primers used are shown in Table 1.

\section{Determination of trehalase activity and carbohydrate content in the brown planthopper after RNAi treatment}

Phosphate buffered saline (PBS) was added to the appropriate tissue sample to obtain a final volume of $200 \mu \mathrm{L}$, and the tissue was disrupted by grinding and sonication. After disruption, $800 \mu \mathrm{L}$ of PBS was added, and the sample was centrifuged at $1000 \mathrm{~g}$ for $20 \mathrm{~min}$ at $4{ }^{\circ} \mathrm{C}$. The supernatant $(350 \mu \mathrm{L})$ was removed and centrifuged at $20,800 \mathrm{~g}$ for $1 \mathrm{~h}$ at $4{ }^{\circ} \mathrm{C}$. The supernatant was used to measure glucose content, total glycogen content, protein concentration, and soluble trehalase activity, and the pellet was resuspended in PBS to determine glucose content, protein concentration, and membrane-bound trehalase activity. The remaining supernatant was used for determination of total protein and trehalose concentrations. The methods used have been described previously (Zhang et al. 2017a).

\section{Analysis of NIPGM CDNA and protein sequences}

NIPGM1 and N1PGM2 cDNA sequences were compared with other phosphoglucomutase sequences present in GenBank using the BLAST-N and BLAST-X tools available on the National Center for Biotechnology Information (NCBI) website (https://blast.ncbi.nlm.nih.gov/Blast.cgi). Multiple sequence alignment of insect PGMs was performed using the tool available at the multiple sequence alignment website (https://bioinfo.genotoul.fr/multalin/multalin.html) and using DNAMAN software. The neighbour-joining method was used to construct a phylogenetic tree based on the amino acid sequences of known PGMs using MEGA 6.0 software. Bootstrap analysis was carried out and the robustness of each cluster was verified using 1000 replicates. NIPGM protein sequences and other analysis criteria used in this study, including MW, pI, and topology were deduced from the corresponding cDNA sequences using the translation tool on the ExPASy proteome prediction tools website (https ://expasy.org/tools/dna.html).

\section{Statistical analysis}

Relative gene copy numbers were determined by qRT-PCR, using the $2^{-\Delta \Delta C T}$ method (Livaka and Schmittgen 2001). All reactions were performed in triplicate and with three biological replicates. The equation were used as follows (Chen et al. 2018):

$2^{-\mathrm{DDCT}}=2^{-[(\mathrm{CT} \text { test group-CT test group } 18 \mathrm{~S})-(\mathrm{CT} \text { control group-CT control 18S })]}$

All the data were analysed using one-way ANOVA and multiple comparisons of the means were conducted using Tukey's test. Differences were considered statistically significant if the $P$ value was between 0.01 and 0.05 , and extremely significant if the $P$ value was less than 0.01 . All data were plotted using SigmaPlot 10.0 software.

\section{Results}

\section{Analysis of NIPGM1 and NIPGM2 sequences}

N1PGM1 (KU556839.1) and N1PGM2 (KU556840.1) cDNAs had open reading frames of 1821 and $1023 \mathrm{bp}$, respectively. NIPGM1 cDNA encoded a protein of 606 amino acids with a predicted mass of approximately 
$68.30 \mathrm{kDa}$ and a pI of 5.89 (Fig. S1A). NIPGM2 encoded a protein of 340 amino acids with a predicted mass of approximately $36.82 \mathrm{kDa}$, and $\mathrm{pI}$ of 6.26. (Fig. S1B).

\section{Phylogenetic and multiple protein alignment analysis}

The PGM protein sequences of Laodelphax striatellus, Osmia bicornis bicornis, Solenopsis invicta, Cimex lectularius, Halyomorpha halys, Monomorium pharaonis, and Ceratina calcarata were selected to determine the homology by alignment with the NIPGM1 protein sequence. The PGM protein sequences of L. striatellus, Frankliniella occidentalis, Locusta migratoria, Melanaphis sacchari, Sarracenia flava, Acyrthosiphon pisum, and Myzus persicae were selected to determine the homology by alignment with the NIPGM2 protein sequence. The results showed that the insect PGMs were highly conserved: the homology of the PGM1 protein of brown planthopper and other insects ranged from 56.77 to $90.59 \%$ (Fig. S2A); the homology of the PGM2 protein ranged from 62.26 to $89.66 \%$ (Fig. S2B).

Phylogenetic analysis using MEGA 6.0 software showed that the NIPGM1 and NIPGM2 proteins could be easily distinguished (Fig. S3). In addition, we found that the PGMs of $N$. lugens and $L$. striatellus could be assigned to the same subgroup (Fig. S3).

\section{Developmental and tissue expression patterns of PGM1 and PGM2}

First, we examined the expression levels of the $P G M 1$ and $P G M 2$ genes at different developmental stages, from the first day of the fourth instar to the third day of adulthood. At the fourth instar nymph stage, $P G M 1$ and $P G M 2$ had different expression patterns. The expression level of $P G M 1$ was relatively stable, while the expression level of $P G M 2$ in the fourth instar nymph increased gradually. The expression levels of $P G M 1$ and $P G M 2$ were high at the initial stage of the fifth instar nymph, and then decreased. At the adult stage, the expression levels of the $P G M 1$ gene were the highest on the first day of adulthood and then decreased significantly and remained at relatively low levels on the second and third days (Fig. 1a, b).

Both $P G M 1$ and $P G M 2$ were most highly expressed in the midgut, followed by the foot. The expression level of the PGMI in the epidermis was lower than in the foot; the expression levels in the head, wings, ovary, and fat body were relatively low overall. The expression level of $P G M 2$ in the fat body was lower than in the foot; the expression levels in the head, foot, wing, and ovary were also relatively low overall (Fig. 1c, d).

\section{Evaluation of the efficiency of RNAi knockdown by dsPGM1 and dsPGM2}

The expression levels of $P G M 1$ and $P G M 2$ were significantly decreased after RNAi for $48 \mathrm{~h}$. Knocking down the $P G M 1$ gene, the relative expression of PGM1 decreased almost 5 times compared to the control group (Fig. 2). In addition, the relative expression of PGM2 in the dsPGM2 group was 33 times lower than that in dsGFP group (Fig. 2). Moreover, compared with the control group injected with dsGFP, the expression levels of the PGM2 gene decreased slightly after the $P G M 1$ knockdown, but this decrease was not significant. The expression level of the $P G M 1$ gene also decreased significantly after the $P G M 2$ knock down (Fig. 2).

\section{Expression of trehalose and glycogen metabolism-related genes following PGM1 or PGM2 knockdown}

The expression of most genes related to trehalose and glycogen metabolism were significantly decreased after knockdown of the $P G M 1$ gene for $48 \mathrm{~h}$, with the exception of the expression level of trehalose-6-phosphate synthase 2 (TPS2), which significantly increased, and the expression level of UDP-glucose pyrophosphorylase (UGPase), which showed no significant change (Fig. 3a). In contrast, the expression levels of TPS1, TPS3, trehalase 2 (TRE2), and hexokinase $(H K)$ were significantly decreased after knockdown of PGM2 for $48 \mathrm{~h}$. The expression levels of TPS2 and UGPase increased significantly, while the remaining genes showed no significant changes (Fig. 3b).

\section{Effects of PGM1 and PGM2 knockdown on glycogen, trehalose, and glucose levels}

Compared with the control group, both the glycogen and glucose contents showed significant increases after PGMI or $P G M 2$ knock down for $48 \mathrm{~h}$. In addition, knockdown of $P G M 1$, but not of $P G M 2$, resulted in a significant increase in the trehalose content (Fig. 4).

\section{Effects of PGM1 and PGM2 knockdown on trehalase activity}

Compared with the dsGFP group, knockdown of $P G M 1$ or $P G M 2$ caused a significant increase in membrane-bound, insoluble, trehalase activity (Fig. 5).

\section{Expression of chitin metabolism-related genes after PGM1 and PGM2 gene knockdown}

Compared with the control group injected with dsGFP, the expression levels of all studied genes related to chitin

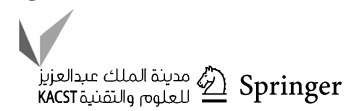




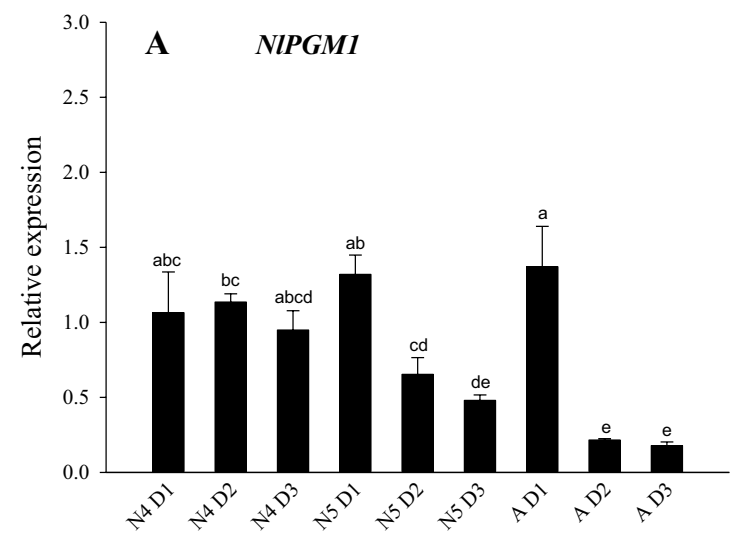

Developmental stage

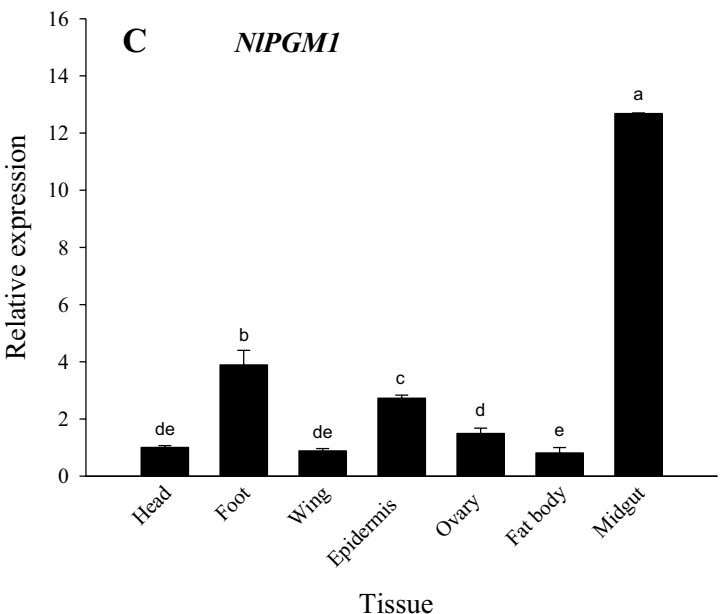

Fig. 1 Relative expression of $P G M 1$ and $P G M 2$ in different tissues and developmental stages in the brown planthopper. Expression patterns of PGM1 (a) and PGM2 (b) at different developmental stages from the first day of the fourth instar nymph to the third day of adulthood. The expression patterns of PGM1 (c) and PGM2 (d) in various tissues including head, foot, wing, epidermis, ovary, and fat body collected from adults. The mRNA levels were normalised to

metabolism were significantly decreased (1-9 times) after the $P G M 1$ knockdown (Fig. 6a). The $P G M 2$ knockdown also significantly decreased the expression of most of the genes involved in chitin metabolism, except for G6PII and G6PI3, which were not significantly changed, and glutamine:fructose6-phosphate aminotransferase (GFAT), which was significantly increased (Fig. 6b). Knockdown of $P G M 1$ and $P G M 2$ also caused clear wing deformities and varying degrees of difficulty in molting (Fig. 6c).

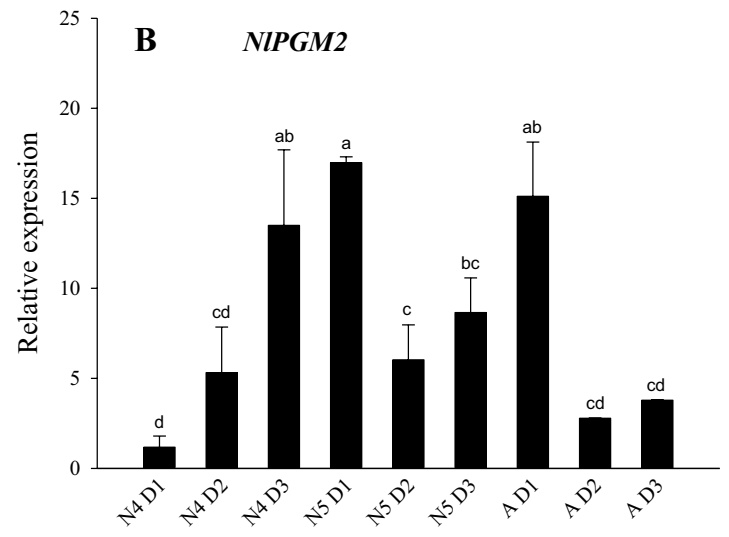

Developmental stage

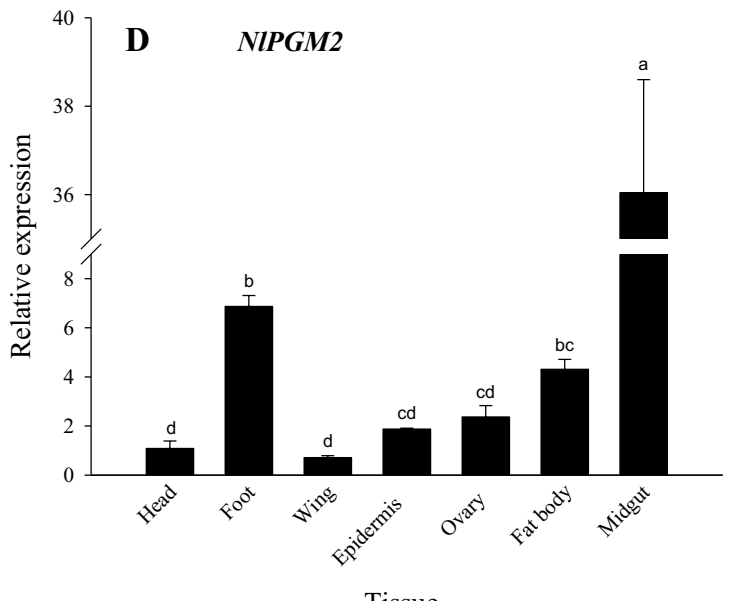

$N$. lugens 18S (Nl18S) mRNA, and the relative expression levels for each tissue and developmental stage were measured in relation to the expression levels obtained in the head of the insects and first day of the fourth instar nymph. One-way analysis of variance (ANOVA) was performed to test for statistical significance. Data are presented as the mean $\pm \mathrm{SD}(N=3)$. Means with different letters within the same group differ significantly, $P<0.05$

\section{Discussion}

According to sequence analysis, PGM1 and PGM2 are highly conserved among different insects, and they are also highly conserved during evolution (Figs. S2, S3). As we all known, PGM catalyses the interconversion of (G-1$\mathrm{P}$ ) and (G-6-P). G-1-P is an important intermediate in the metabolism of glycogen, galactose, glycoproteins, and 


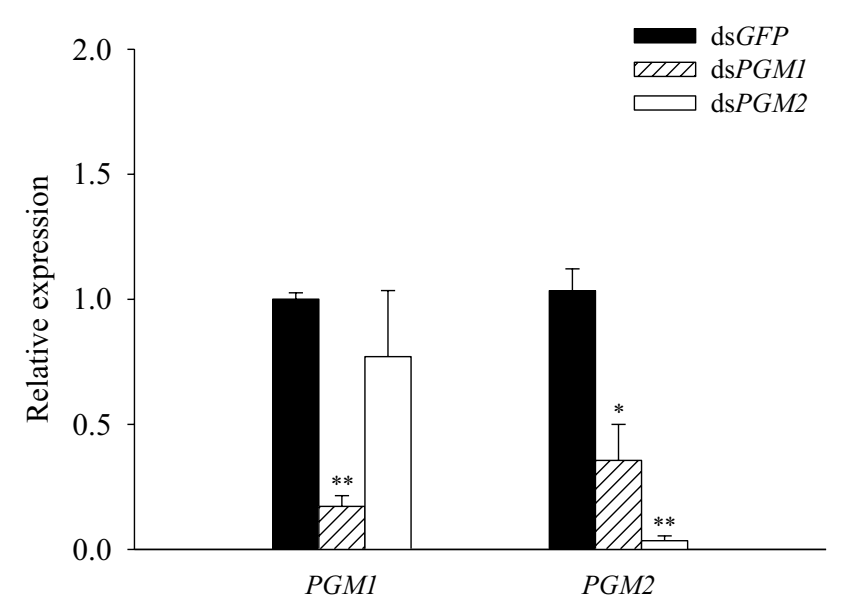

Fig. 2 Relative expression levels of $P G M 1$ and $P G M 2$ after RNAi. mRNA levels of NIPGM1 and NIPGM2 relative to the Nl18S RNA level following RNAi targeting. The first day of the fifth instar nymph was chosen for dsRNA injection. *Indicates a significant difference and $* *$ indicates an extremely significant difference

glycolipids; therefore, PGM is involved in a variety of cellular functions (Hakomori 1985; Gahmberg and Hakomori 1973; Novelli and Reichardt 2000). G-6-P is a central, metabolite, part of glycolysis and the pentose phosphate pathway, providing precursors for anabolic pathways and cofactors required for cell proliferation (Ward and Thompson 2012). PGM is widely found in animals, plants, and microorganisms and is distributed in almost all tissues (Egli et al. 2010; Stray-Pedersen et al. 2014; Weyler and Heinzle 2015). In the brown planthopper, both $P G M 1$ and $P G M 2$ were most highly expressed in the midgut, followed by the foot (Fig. 1c, d). While the role of PGM in the intestine is likely related to nutrient intake and utilisation and heterogeneous metabolism (insecticide metabolism) (Bao et al. 2012), we speculate that PGM may also play an important role in substance metabolism in the brown planthopper. Given that the $P G M 1$ and $P G M 2$ genes are highly expressed on the first day of the fifth instar and on the first day of the adult (Fig. 1a, b), PGM1 and PGM2 may play an important role in chitin synthesis.

RNAi technology has become an effective tool in the research of insect gene function, gene expression regulation, pest control, and new pesticide development (Lou et al. 2018; Han et al. 2018). Although the brown planthopper is an agricultural pest, it is also a desirable model insect to study gene function (Xi et al. 2015a, b). We used RNAi technology to explore the role of $P G M$ in regulating the metabolism of trehalose and glycogen in the brown planthopper. To verify the specificity and effectiveness of dsPGM1 and dsPGM2 for RNAi, we first examined the relative expression levels of $P G M 1$ and $P G M 2$ after injection with dsPGM1 and dsPGM2, respectively. We found that the relative expression
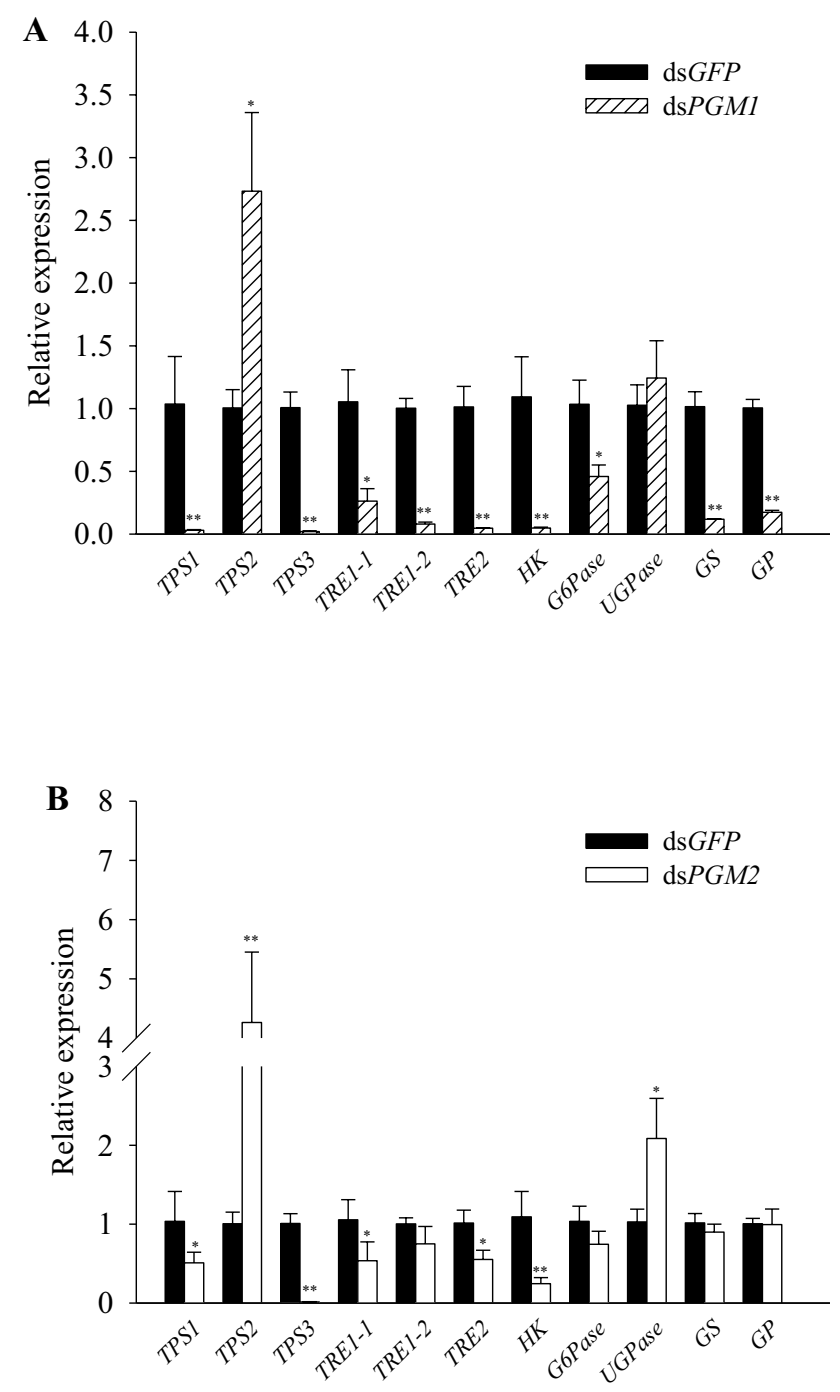

Fig. 3 Expression levels of trehalose and glycogen metabolic pathway genes after RNAi. The expression levels of three trehalose-6-phosphate synthases (TPSs), three trehalases (TREs), hexokinase (HK), glucose-6-phosphatase (G6Pase), UDP-glucose pyrophosphorylase (UGPase), glycogen synthase (GS), and glycogen phosphorylase (GP) at $48 \mathrm{~h}$ relative to the $N$. lugens $18 \mathrm{~S}$ (Nl18S) RNA level following PGM1 (a) or PGM2 (b) knockdown

levels of $P G M 1$ and $P G M 2$ were significantly decreased after RNAi injection $(P<0.01)$. In addition, the $P G M I$ levels were relatively unaffected after $P G M 2$ knockdown, whereas the $P G M 2$ expression levels were significantly decreased after $P G M 1$ knockdown (Fig. 2). This suggests that the expression level of $P G M 1$ may affect the expression level of $P G M 2$.

Trehalose is the blood sugar in insects and critical for insect growth, development, and molting (Elbein 1974; Elbein et al. 2003; Tang et al. 2014). Glycogen is an important energy store. The expression levels of the genes involved in trehalose and glycogen metabolism were significantly

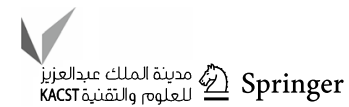


down-regulated after the PGMI knocking down (Fig. 3a). Although some genes were unaffected by the knockdown of PGM2, others showed a slight down-regulation (Fig. 3b). The trehalose content was significantly increased after the dsPGM1 injection, but no significant effect was observed after the dsPGM2 injection (Fig. 4). This is consistent with the extremely low expression levels of the TRE genes and a significant increase of expression in the TPS2 gene following the dsPGM1 injection (Fig. 3). Previous studies have shown that when different types of TRE genes are knocked down, the changes in trehalose content are different (Yang et al. 2017; Chen et al. 2010), which may explain why the trehalose content differs after injection of dsPGM1 compared to dsPGM2.

The glucose levels were also significantly increased after injection of both dsPGM1 and dsPGM2 (Fig. 4). This is consistent with the several-fold higher expression level of G6Pase compared to the expression level of $H K$, even

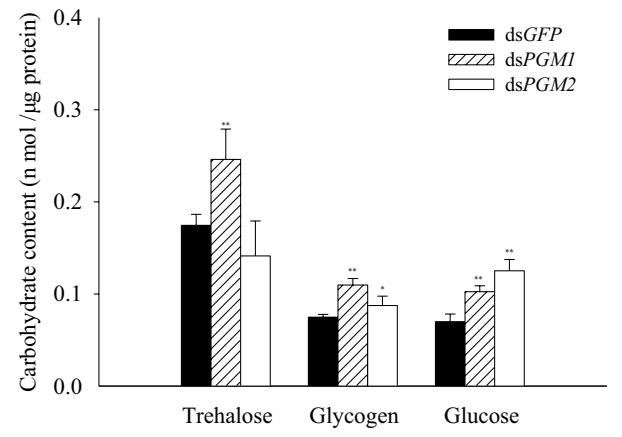

Fig. 4 Trehalose, glycogen, and glucose content of $N$. lugens after RNAi. All measurements were performed in triplicate

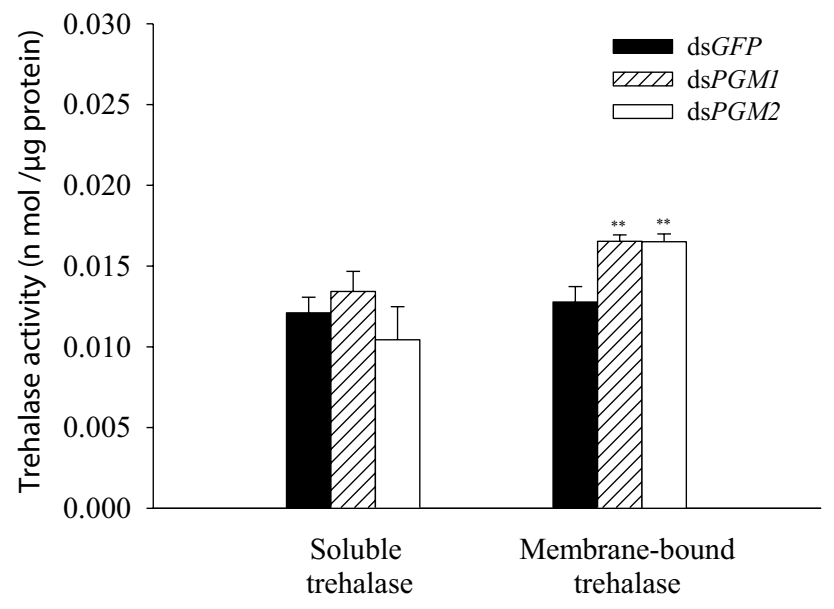

Fig. 5 Trehalase 1 (soluble trehalase, a) and trehalase 2 (membranebound trehalase, $b$ ) activities after RNAi. All measurements were performed in triplicate though $H K$ and G6Pase were both suppressed by dsPGM1 and dsPGM2 (Fig. 3). Studies have shown that knockdown of the HR38 gene in Aedes aegypti can block transcriptional activation of the $C M$ gene encoding PGM and TPS, resulting in increased glycogen accumulation (Dong et al. 2018). Here, we also found that the levels of glycogen in the brown planthopper were significantly increased after injection of dsPGM1 and dsPGM2 (Fig. 4). Trehalose and trehalase activity are key for the regulation of various physiological processes in insects (Ge et al. 2011). Membranebound trehalase activity was significantly increased after dsPGM1 or dsPGM2 injection, whereas soluble trehalase activity was not significantly altered (Fig. 5). These results indicate that $P G M 1$ and $P G M 2$ may have greater effect on membrane-bound trehalase than on the soluble form of the enzyme.

An increasing number of studies have shown that trehalose metabolism can regulate the synthesis of chitin through trehalose synthase and trehalose hydrolase (Tang et al. 2010; Shukla et al. 2015; Shi et al. 2016; Yang et al. 2017). Knockdown of the TRE gene in the brown planthopper caused clear deformities in the wings and difficulty in molting, indicating that trehalose has a direct effect on chitin synthesis (Zhang et al. 2017a). Abnormal synthesis of chitin has also been observed in the brown planthopper after knockdown of the TPS gene (Yang et al. 2017). In this study, both the TPS and TRE genes were affected to some degree after knockdown of the $P G M 1$ or $P G M 2$ genes; therefore, we further tested the effect of $P G M 1$ or $P G M 2$ knockdowns on chitin synthesis. The expression of most of the genes involved in chitin synthesis were significantly decreased after ds $P G M 1$ or dsPGM2 injection (Fig. 6a, b), and there were different degrees of deformity (Fig. 6c), suggesting that silencing the $P G M 1$ or $P G M 2$ genes can inhibit the expression of chitin synthase $(C H S)$, resulting in the inability of the brown planthopper to synthesise chitin. Recently, in a study in the A. pisum nymph, knockdown of $A$. pisum $C H S$ was found to disrupt embryonic development, leading to difficulty in molting (Ye et al. 2019). Another study in whitebacked planthoppers showed malformations and high mortality after CHS1, CHS1a, and CHS1b knockdown (Wang et al. 2019). These studies demonstrate that CHS plays a pivotal role in chitin synthesis, which is consistent with our results.

\section{Conclusions}

The expression patterns of the $P G M 1$ and $P G M 2$ genes were similar, both at different developmental stages and in different tissues. RNAi using dsPGM1 and dsPGM2 effectively inhibited the expression of their respective target genes and disrupted the normal metabolic balance between glycogen and trehalose, which affected chitin metabolism. 
Fig. 6 Expression levels of genes in the chitin metabolic pathway and the resulting abnormal phenotype after RNAi. a, b Expression levels of three glucose-6-phosphate isomerases (G6PIs), glutamine: fructose-6-phosphate aminotransferase (GFAT), glucosamine-6-phosphate $N$-acetyltransferase (GNPNA), UDP- $N$-acetylglucosamine pyrophosphorylase (UAP), and three chitin synthases (CHSs) relative to the $N$. lugens $18 \mathrm{~S}$ (Nl-18S) RNA level. c Abnormal insects at the larva-adult stage
A

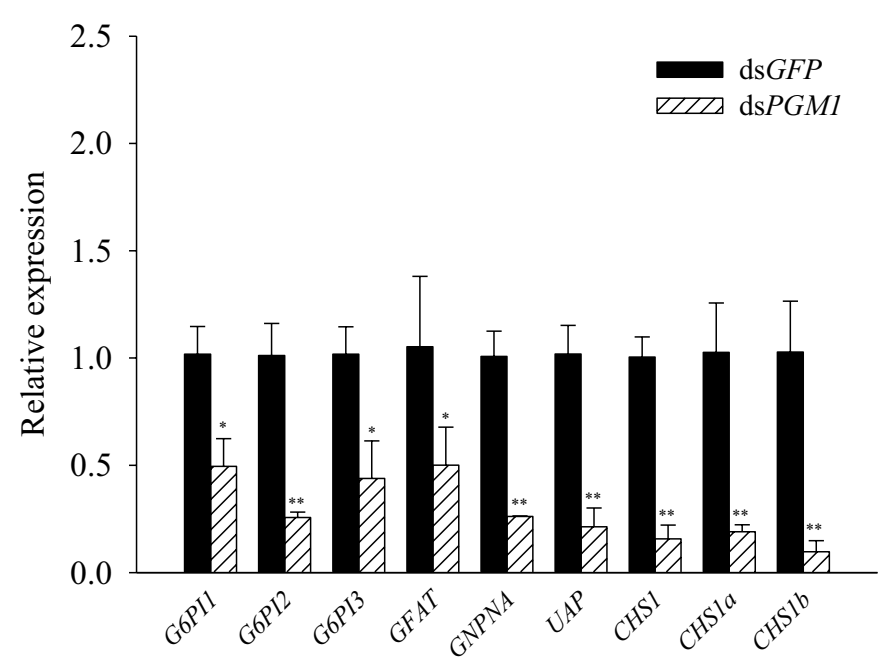

B

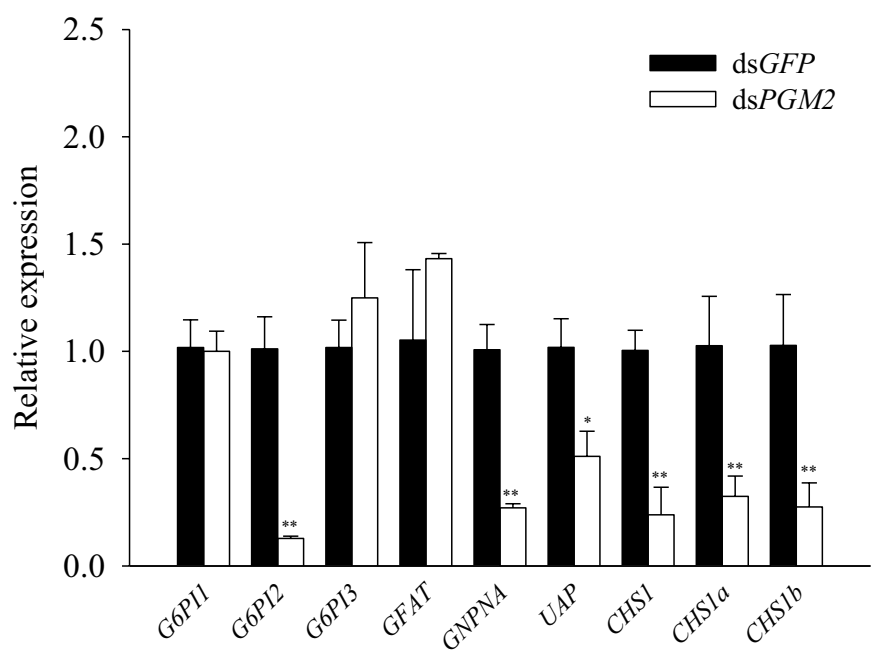

C

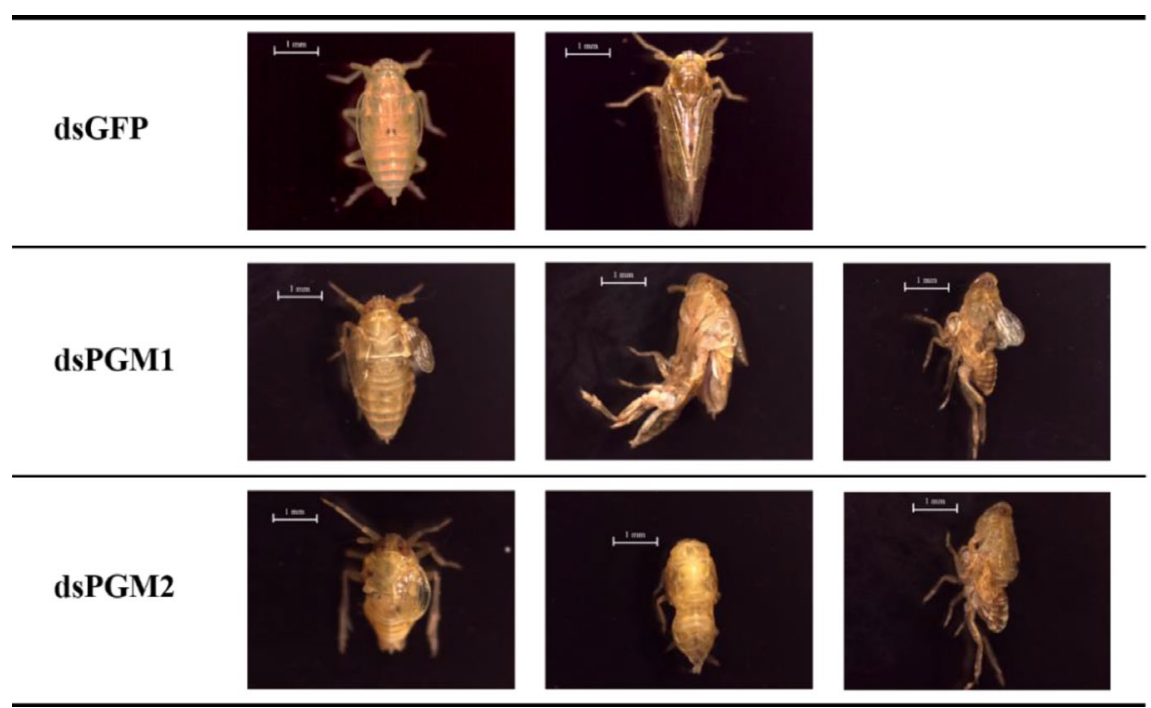




\section{Conflict of interest}

The authors declare that the research was conducted in the absence of any commercial or financial relationships that could be construed as a potential conflict of interest.

Acknowledgements This work was supported by the National Natural Science Foundation of China (Grant Nos. 31672081).

Open Access This article is licensed under a Creative Commons Attribution 4.0 International License, which permits use, sharing, adaptation, distribution and reproduction in any medium or format, as long as you give appropriate credit to the original author(s) and the source, provide a link to the Creative Commons licence, and indicate if changes were made. The images or other third party material in this article are included in the article's Creative Commons licence, unless indicated otherwise in a credit line to the material. If material is not included in the article's Creative Commons licence and your intended use is not permitted by statutory regulation or exceeds the permitted use, you will need to obtain permission directly from the copyright holder. To view a copy of this licence, visit http://creativecommons.org/licenses/by/4.0/.

\section{References}

Bao YY, Wang Y, Wu WJ, Zhao D, Xue J, Zhang BQ, Shen ZC, Zhang CX (2012) De novo intestine-specific transcriptome of the brown planthopper Nilaparvata lugens revealed potential functions in digestion, detoxification and immune response. Genomics 99(4):256-264

Becker A, Schlöder P, Steele JE, Wegener G (1996) The regulation of trehalose metabolism in insects. Experientia 52(5):433-439

Boddupally D, Tamirisa S, Gundra SR, Vudem DR, Khareedu VR (2018) Expression of hybrid fusion protein (Cry1Ac:ASAL) in transgenic rice plants imparts resistance against multiple insect pests. Sci Rep 8:8458

Bottrell DG, Schoenly KG (2012) Resurrecting the ghost of green revolutions past: the brown planthopper as a recurring threat to high-yielding rice production in tropical Asia. J Asia Pac Entomol 15(1):122-140

Chen J, Tang B, Chen HX, Yao Q, Huang XF, Chen J, Zhang DW, Zhang WQ (2010) Different functions of the insect soluble and membrane-bound trehalase genes in chitin biosynthesis revealed by RNA interference. PLoS ONE 5(4):e10133

Chen QW, Jin S, Zhang L, Shen QD, Wei P, Wei CM, Wang SG, Tang B (2018) Regulatory functions of trehalose-6-phosphate synthase in the chitin biosynthesis pathway in Tribolium castaneum (Coleoptera:Tenebrionidae) revealed by RNA interference. Bull Entomol Res 108(3):388-399

Cheng X, Zhu L, He G (2013) Towards understanding of molecular interactions between rice and the brown planthopper. Mol Plant 6:621-634

Dong D, Zhang Y, Smykal V, Ling L, Raikhel AS (2018) HR38, an ortholog of NR4A family nuclear receptors, mediates 20-hydroxyecdysone regulation of carbohydrate metabolism during mosquito reproduction. Insect Biochem Mol 96:19-26

Egli B, Kölling K, Köhler C, Zeeman SC, Streb S (2010) Loss of cytosolic phosphoglucomutase compromises gametophyte development in Arabidopsis. Plant Physiol 154(4):1659-1671

Elbein AD (1974) The metabolism of $\alpha, \alpha$-trehalose. In: Advances in carbohydrate, bioscience, biotechnology, biochemistry, vol 30, pp $227-256$
Elbein AD, Pan YT, Pastuszak I, Carroll D (2003) New insights on trehalose: a multifunctional molecule. Glycobiology 13(4):17R-27R

Gahmberg CG, Hakomori SI (1973) Altered growth behavior of malignant cells associated with changes in externally labeled glycoprotein and glycolipid. Proc Natl Acad Sci USA 70(12):3329-3333

Ge LQ, Zhao KF, Huang LJ, Wu JC (2011) The effects of triazophos on the trehalose content, trehalase activity and their gene expression in the brown planthopper Nilaparvata lugens (Stål) (Hemiptera:Delphacidae). Pestic Biochem Phys 100(2):172-181

Hakomori S (1985) Aberrant glycosylation in cancer cell membranes as focused on glycolipids: overview and perspectives. Cancer Res 45:2405-2414

Han YH, Liu MY, Zhang HZ, Wang MZ, Gao F, Wang MQ, Liu CX, Chen HY (2018) Application of RNA interference on researches of diapause mechanism in insects. J Environ Entomol 40(06):1248-1254 (in Chinese)

Jin GZ, Zhang Y, Cong WM, Wu XY, Wang XG, Wu SY, Wang S, Zhou WP, Yuan SG, Gao H, Yu GZ, Yang WW, Christofk H (2018) Phosphoglucomutase 1 inhibits hepatocellular carcinoma progression by regulating glucose trafficking. PLoS Biol 16(10):e2006483

Liu L (2013) Research progress of phosphoglucomutase in microorganism. J Anhui Agric Sci 7(7):2821-2822 (in Chinese)

Liu Z, Gong P, Heckel DG, Wei W, Sun J, Li D (2009) Effects of larval host plants on over-wintering physiological dynamics and survival of the cotton bollworm, Helicoverpa armigera (Hubner) (Lepidoptera:Noctuidae). J Insect Physiol 55:1-9

Livaka KJ, Schmittgen TD (2001) Analysis of relative gene expression data using real-time quantitative PCR and the 2 (-Delta Delta C (T)) method. Methods 25(4):402-408

Lou YH, Pan PL, Ye YX, Cheng C, Xu HJ, Zhang CX (2018) Identification and functional analysis of a novel chorion protein essential for egg maturation in the brown planthopper. Insect Mol Biol 27(3):393-403

Malinova I, Kunz HH, Alseekh S, Herbst K, Fernie AR, Gierth M, Fettke J (2014) Reduction of the cytosolic phosphoglucomutase in Arabidopsis reveals impact on plant growth, seed and root development, and carbohydrate partitioning. PLoS ONE 9(11):e112468

Nauen R, Denholm I (2005) Resistance of insect pests to neonicotinoid insecticides: current status and future prospects. Arch Insect Biochem 58:200-215

Novelli G, Reichardt JKV (2000) Molecular basis of disorders of human galactose metabolism: past, present, and future. Mol Genet Metab 71(1-2):62-65

Paparelli E, Parlanti S, Gonzali S, Novi G, Mariotti L, Ceccarelli N, Dongen JT, Kölling K, Zeeman SC, Perata P (2013) Nighttime sugar starvation orchestrates gibberellin biosynthesis and plant growth in Arabidopsis. Plant Cell 25(10):3760-3769

Shi ZK, Liu XJ, Xu QY, Qin Z, Wang S, Zhang F, Wang SG, Tang B (2016) Two novel soluble trehalase genes cloned from Harmonia axyridis and regulation of the enzyme in a rapid changing temperature. Comp Biochem Physiol B Biochem Mol Biol 198:10-18

Shukla E, Thorat LJ, NATH BB, Gaikwad MS (2015) Insect trehalase: physiological significance and potential applications. Glycobiology 25(4):357-367

Stray-Pedersen A, Backe PH, Sorte HS, Mørkrid L, Chokshi NY, ErIchsen HC, Gambin T, Elgstøen KB, Bjørås M, Wlodarski MW, Krüger M, Jhangiani SN, Muzny DM, Patel A, Raymond KM, Sasa GS, Krance RA, Martinez CA, Abraham SM, Speckmann C, Ehl S, Hall P, Forbes LR, Merckoll E, Westvik J, Nishimura G, Rustad CF, Abrahamsen TG, Rønnestad A, Osnes LT, Egeland T, Rødningen OK, Beck CR, Baylor-Johns Center for Mendelian Genomics, Boerwinkle EA, Gibbs RA, Lupski JR, Orange JS, Lausch E, Hanson IC (2014) PGM3 mutations cause a congenital disorder of glycosylation with severe immunodeficiency and skeletal dysplasia. Am J Hum Genet 95(1):96-107 
Tanaka K, Endo S, Kazano H (2000) Toxicity of insecticides to predators of rice planthoppers: spiders, the mirid bug and the dryinid wasp. Appl Entomol Zool 35:177-187

Tang B, Chen J, Yao Q, Pan ZQ, Xu WH, Wang SG, Zhang WQ (2010) Characterization of a trehalose-6-phosphate synthase gene from Spodoptera exigua and its function identification through RNA interference. J Insect Physiol 56(7):813-821

Tang B, Xu Q, Zou Q, Fang Q, Wang SG, Ye GY (2012) Sequencing and characterization of glycogen synthase and glycogen phosphorylase genes from Spodoptera exigua and analysis of their function in starvation and excessive sugar intake. Arch Insect Biochem 80(1):42-62

Tang B, Qin Z, Shi ZK, Wang S, Guo XJ, Wang SG, Zhang F (2014) Trehalase in Harmonia axyridis (Coleoptera:Coccinellidae): effects on beetle locomotory activity and the correlation with trehalose metabolism under starvation conditions. Appl Entomol Zool 49(2):255-264

Tang B, Shen QD, Zeng BP, Xiao ZJ, Qiu LY, Pan BY, Li K, Zhang DW (2019) Characteristics, developmental expression and RNAi effect analysis of a novel trehalose-6-phosphate synthase gene in Nilaparvata lugens. Sci Agric Sin 52(03):466-477 (in Chinese)

Tolmasky DS, Rabossi A, Quesada-Allué LA (2001) Synthesis and mobilization of glycogen during metamorphosis of the medfly Ceratitis capitata. Arch Biochem Biophys 392(1):0-47

Wang Z, Yang H, Zhou C, Yang WJ, Jin DC, Long GY (2019) Molecular cloning, expression, and functional analysis of the chitin synthase 1 gene and its two alternative splicing variants in the whitebacked planthopper, Sogatella furcifera (Hemiptera:Delphacidae). Sci Rep 9:1087

Ward P, Thompson C (2012) Metabolic reprogramming: a cancer hallmark even warburg did not anticipate. Cancer Cell 21(3):297-308
Weyler C, Heinzle E (2015) Multistep synthesis of UDP-glucose using tailored, permeabilized cells of E. coli. Appl Biochem Biotechnol 175(8):3729-3736

Xi Y, Pan PL, Zhang CX (2015a) The $\beta$ - $n$-acetylhexosaminidase gene family in the brown planthopper Nilaparvata lugens. Insect Mol Biol 24(6):601-610

Xi Y, Pan PL, Ye YX, Yu B, Xu HJ, Zhang CX (2015b) Chitinase-like gene family in the brown planthopper Nilaparvata lugens. Insect Mol Biol 24(1):29-40

Yang MM, Zhao LN, Shen QD, Xie GQ, Wang SG, Tang B (2017) Knockdown of two trehalose-6-phosphate synthases severely affects chitin metabolism gene expression in the brown planthopper Nilaparvata lugens. Pest Manag Sci 73:206-216

Ye C, Jiang YD, An X, Yang L, Shang F, Niu J, Wang JJ (2019) Effects of RNAi-based silencing of chitin synthase gene on moulting and fecundity in pea aphids (Acyrthosiphon pisum). Sci Rep 9:3694

Zhang L, Qiu LY, Yang HL, Wang HJ, Zhou M, Wang SG, Tang B (2017a) Study on the effect of wing bud chitin metabolism and its developmental network genes in the brown planthopper, Nilaparvata Lugens, by knockdown of TRE gene. Front Physiol 8:750

Zhang L, Zhu SC, Zheng H, Shen QD, Wang SG, Tang B (2017b) Regulatory function of trehalase genes on chitin metabolism in the cuticle of Nilaparvata lugens. Sci Agric Sin 50(6):1047-1056 (in Chinese)

Zhao LN, Yang MM, Shen QD, Liu XJ, Shi ZK, Wang SG, Tang B (2016) Functional characterization of three trehalase genes regulating the chitin metabolism pathway in rice brown planthopper using RNA interference. Sci Rep 6:27841 